metzler kompakt 


\section{Deutschsprachige Autoren}

\section{Porträts}

Verlag J. B. Metzler Stuttgart - Weimar 
Die in diesem Band versammelten Autorenporträts stammen aus der dritten Auflage des "Metzler Autoren Lexikons" (2004). Dort befinden sich auch weiterführende Literaturhinweise zu jedem der Artikel.

\section{Bibliografische Information}

Der Deutschen Bibliothek

Die Deutsche Bibliothek verzeichnet diese

Publikation in der Deutschen National-

bibliografie; detaillierte bibliografische

Daten sind im Internet über

$<$ http://dnb.ddb.de > abrufbar.

ISBN 978-3-476-02027-7

ISBN 978-3-476-02950-8 (eBook)

DOI 10.1007/978-3-476-02950-8

Dieses Werk einschließlich aller seiner Teile ist urheberrechtlich geschützt. Jede Ver-

wertung außerhalb der engen Grenzen des Urheberrechtsgesetzes ist ohne Zustimmung des Verlages unzulässig und strafbar. Das gilt insbesondere für Vervielfältigungen, Übersetzungen, Mikroverfilmungen und die Einspeicherung und Verarbeitung in elektronischen Systemen.

() 2004 Springer-Verlag GmbH Deutschland Ursprünglich erschienen bei J.B. Metzler'sche Verlagsbuchhandlung und Carl Ernst Poeschel Verlag $2004 \mathrm{GmbH}$ in Stuttgart

www.metzlerverlag.de info@metzlerverlag.de 